\title{
PARTISIPASI DOSEN TERHADAP HASIL BELAJAR MAHASISWA PROGRAM STUDI S-1 PENDIDIKAN TEKNIK SIPIL FT. UNJ
}

\author{
Ir. M. Nuriman Thoha S
}

\begin{abstract}
Abstrak
Secara umum tujuan penelitian dalam rangka upaya perbaikan faktor internal mahasiswa melalui faktor eksternal dalam hal ini partisipasi dosen. Secara khusus menginformasikan bagaimana kecenderungan partisipasi dosen yang diukur dari tingkat kehadirannya di kelas, membantu mahasiswa dalam tujuan dan prinsip kuliah, frekuensi bimbingan, diskusi dan umpan balik, transparansi hasil evaluasi atau tes serta melakukan reviu secara berkala dalam upaya meningkatkan keberhasilan belajar mahasiswa diukur dari indeks prestasi, serta bagaimana hubungan antara partisipasi dosen dengan keberhasilan belajar mahasiswa di Program Studi Jurusan Teknik Sipil, Fakultas Teknik, Universitas Negeri Jakarta.

Penelitian ini dilakukan di Jurusan Teknik Sipil FT-UNJ selama periode Agustus sampai Oktober 2004. Sampel secara acak di ambil 35 dari 199 mahasiswa. Untuk menjabarkan data digunakan metode deskriptif dan korelasi untuk menguji hipotesis. Berdasarkan jenis kelamin responden lakilaki $(45,7 \%)$ dan perempuan (54,3\%) dengan 41 - 60 SKS yang mempunyai prosentase terbesar serta IPK 2,51 - 3,00 sebesar 48,57\%.

Pada taraf nyata 0,05, menunjukan bahwa; (1), dari sembilan variabel yang di analisis hanya lima yang mempunyai hubungan yang positif yaitu; kehadiran dosen $\left(X_{1}\right)$ persamaannya $Y=1,501+0,361 X_{1}$, Tujuan kuliah $\left(X_{2}\right)$ dengan $Y=1,395+0,598 X_{2}$, Konsep/Prinsip Kuliah $\left(X_{3}\right)$ dengan $Y=$ $1,585+0,572 X_{3}$, Frekuensi Bimbingan $\left(X_{5}\right)$ dengan $Y=1,397+0,459 X_{5}$, Diskusi/umpan Balik $\left(X_{7}\right)$ dengan $Y=1,436+0,565 X_{7}$, dan transparansi Evaluasi/hasil tes $\left(X_{8}\right)$ dengan $Y=1,830+0,393 X_{8}$ (2) Terdapat hubungan positif antara $(X)$ secara bersama-sama dengan $(Y)$ dengan kekuatan hubungan 0,947 dan 87,5\% variasi indek prestasi kumulatif mahasiswa ditentukan oleh adanya kontribusi partisipasi dosen, dengan persamaan $; \hat{\boldsymbol{Y}}=$ $0,363+0,063 X_{1}+0,336 X_{2}+0,0543 X_{3}+0,08247 X_{5}+0,291 X_{7}-0,0579$ $X_{8}$
\end{abstract}


Kata Kunci: Partisipasi Dosen, Hasil Belajar, Faktor Internal, Faktor Eksternal

\section{A. PENDAHULUAN}

\section{Latar Belakang Masalah}

Perkembangan ilmu pengetahuan dan teknologi yang demikian pesat akan menimbulkan beberapa perubahan dan membawa dampak kemajuan di segala bidang, termasuk didalamnya perkembangan sektor industri konstruksi yang demikian pesatnya. Perkembangan ini akan mempengaruhi berbagai aspek kehidupan masyarakat Indonesia. Tingkat kebutuhan hidup meningkat, baik itu kebutuhan lahiriah maupun batiniah. Tingkat kebutuhan akan ilmu pengetahuanpun meningkat. Apalagi jika melihat perkembangan liberalisasi perdagangan. Hal ini telah memicu persaingan ketat antara pelaku-pelaku ekonomi, secara nyata akan ditemui saat AFTA tahun 2003 yang sudah berlaku dan WTO tahun 2005, serta APEC tahun 2020. Lintas tenaga kerja yang profesional antar negara tak dapat di hindarkan. Syarat utama keberhasilan dalam pasar bebas adalah efesiensi dalam berproduksi, modal penggeraknya adalah dana, penguasahaan ilmu pengetahuan dan teknologi serta sumber daya manusia yang handal.

Beberapa kesempatan terbuka bagi lulusan program studi Pendidikan Teknik Sipil (Selanjutnya disebut Pend. TS) di masa depan di tingkat nasional, regional mapupun international, yang tidak hanya dalam bidang pendidikan. Beberapa kesempatan tersebut antara lain (1) dalam bidang industri konstruksi, (2) dalam industri kecil dan menengah, (3) Tenaga staff dalam dunia industri, (4) Laboran dalam industri pendukung konstruksi, (5) guru dalam bengkel ataupun dalam bagian pelatihan di Industri, dan (6) industri kerajinan tangan.

Melihat trend industri saat ini terlepas dari krisis ekonomi, kemungkinan pertumbuhan industri konstruksi dimasa depan untuk 5 tahun kedepan cukup tinggi. Sebagai indikatornya adalah dengan akan dibangunnya subway dari BlokM ke kota, kemudian rencana pembangunan tunnel Jawa-Sumatera atau jembatan yang menguhubungkannya (Seminar Tunneling 2000). Minimal perkembangan industri konstruksi ini melanjutkan pekerjaan yang tertunda karena krisis ekonomi ataupun pekerjaan-pekerjaan yang kecil dan menengah. Seperti outer ring road Jakarta, underpass, flyover dan lainnya disektor 
perumahan. Hal ini membuka peluang kerja. Kesempatan bagi lulusan program studi Pend. TS akan kecil jika tanpa didukung oleh pengetahuan, kemampuan dan kepribadian mahasiswa yang andal. Konsekwensinya memenuhi keinginan pasar akan kualitas lulusan yang handal.

Bagi lulusan baru, seleksi awal yang diberikan bagi perusahaan jasa konstruksi adalah syarat indek prestasi kumulatif (IPK), umumnya kriteria minimal yang dibutuhkan adalah 2,75, selain kemampuan lainnya. IPK dalam pasar kerja sebenarnya belum menjamin tingkat professionalisme seseorang dalam bidangnya. Akan tetapi hal ini merupakan syarat awal untuk melihat kemampuan seseorang dalam bidang akademik, untuk dapat mengikuti seleksi awal, hal ini tercermin dalam banyak iklan lowongan kerja di media massa.

IPK merupakan Indikator dari keberhasilan belajar seorang mahasiswa. Banyak hal yang mempengaruhi keberhasilan ini, secara garis besar dibagi menjadi dua faktor eksternal dan internal. Faktor internal adalah faktor yang dimiliki oleh mahasiswa dan dapat dikontrol oleh mahasiswa. Faktor eksternal adalah faktor yang tidak dapat secara langsung dikontrol oleh mahasiswa dan akan tetapi secara langsung mempengaruhi faktor internal. Beberapa faktor internal seperti kualitas input (calon mahasiswa), kemampuan ekonomi, ras, daya tangkap dan lainnya adalah hal yang dapat dikendalikan oleh mahasiswa. Faktor eksternal seperti, sarana dan prasarana serta penunjang lainya, suasana akademik yang kondusif, kualitas partisifasi dosen, metode pembelajaran, kurikulum yang sesuai kebutuhan pasar dan beberapa kebijakan manajemen jurusan, merupakan faktor yang tidak dapat secara langsung dikendalikan oleh mahasiswa. Secara signifikan faktor eksternal akan mempengaruhi keberhasilan belajar. Jika perumpamaan ini dianggap sebagai sistem, mahasiswa merupakan input dan proses merupakan strategi manajemen jurusan dalam menghasilkan output. Output dalam hal ini keberhasilan belajar mahasiswa, indikatornya adalah IPK.

\section{Perumusan dan Pembatasan Masalah}

Sejumlah pertanyaan dan masalah yang perlu dijawab dan dipecahkan berdasarkan uraian di atas akan tetapi dalam penelitian yang dilakukan hanya mengkaji bagaimanakah partisipasi dosen di jurusan teknik sipil? Partisipasi dosen diukur berdasarkan faktor-faktor dari luar diri mahasiswa yang meliputi; kehadiran dosen, tujuan kuliah, prinsip kuliah, media pembelajaran inovativ, 
frekuensi bimbingan, unjuk kerja mahasiswa, diskusi dan umpan balik, transparansi hasil test, dan perkuatan retensi. Faktor tersebut dikaitkan dengan bagaimanakah keberhasilan belajar mahasiswa sebagai anak didiknya yang diukur dari keberhasilan belajarnya ditunjukan melalui Indek Prestasi Kumulatif? Penelitian ini dibatasi bagi mahasiswa yang telah menempuh minimal 4 (empat) semester.

3. Tujuan Penelitian

Secara umum sebagai dasar pengambilan kebijakan dalam rangka upaya perbaikan faktor internal mahasiswa melalui faktor eksternal dalam hal ini partisipasi dosen. Secara khusus memberikan informasi mengenai; (1) Bagaimana kecenderungan partisipasi dosen yang diukur dari tingkat kehadirannya di kelas, membantu mahasiswa dalam tujuan dan prinsip kuliah, frekuensi bimbingan, diskusi dan umpan balik, transparansi hasil evaluasi atau tes serta melakukan reviu secara berkala, di Program Studi Jurusan Teknik Sipil, Fakultas Teknik, Universitas Negeri Jakarta. (2) Bagaimana kecenderungan tingkat keberhasilan belajar mahasiswa diukur dari indeks prestasi, di Program Studi Jurusan Teknik Sipil, Fakultas Teknik, Universitas Negeri Jakarta . (3) Bagaimana hubungan antara partisipasi dosen terhadap hasil belajar mahasiswa?

\section{B. KERANGKA TEORI DAN PERUMUSAN HIPOTESIS}

\section{Kerangka Teori}

Mahasiswa sebagai setiap individu, mempunyai kemampuan belajar yang berlainan, sehingga hasilnya akan berbeda, sehingga hal ini akan memerlukan satu sistem yang tepat dalam melakukan proses pendidikan terhadap mahasiswa sebagai bagian dari sistem pendidikan. Pendidikan sendiri seringkali dijelaskan melalui sudut pandang yang berbeda-beda. Ahli sosiologi akan mengartikan pendidikan sebagai usaha pewarisan dari generasi ke generasi. Pakar antropologi mengartikan pemindahan nilai-nilai dan pengetahuan ke generasi berikutnya. Menurut ahli ekonomi sebagai bagian dari suatu investasi sumber daya manusia untuk membentuk sdm dalam pembangunan bangsa. Hal ini menurut Banathy (1991) sebagai penjelasan yang fragmented and disconnected. Pendekatan fragmented ini

Partisipasi Dosen Terhadap Hasil Belajar Mahasiswa Program Studi S-1 Pendidikan Teknik Sipil FT-UNJ (Nuriman Thoha, Dosen Jurusan Teknik Sipil FT-UNJ) 
merupakan penjelasan yang terputus-putus disebut sebagai monodisipliner. Padahal pendidikan perlu dijelaskan secara integral, lengkap dan utuh, yang merupakan pandangan multidisipliner atau sebagai pendekatan sistem. (Pannen, 2001).

Pendidikan sebagai suatu sistem memperoleh masukan dari supra sistem dan memberikan hasil (keluaran) bagi supra sistem. Masukannya adalah tata nilai, cita-cita, norma dalam masyarakat, mahasiswa, dosen, personalia dan biaya pendidikan (Pannen, 2001). Menurut Coombs dalam Mudyahardjo (1993) ada 12 sub sistem pendidikan yang keberhasilannya ditentukan oleh interaksi fungsional sub-sistem secara keseluruhan, yaitu: tujuan, mahasiswa, manajemen, struktur dan jadwal waktu, materi pendidikan, tenaga pengajar dan pelaksana, alat bantu pengajaran atau media, fasilitas, teknologi, kendali mutu, penelitian dan biaya pendidikan. Pendidikan juga dapat menimbulkan motivasi tertentu dalam diri individu. Motivasi dapat didefinisikan sebagai tenaga pendorong atau yang menyebabkan perubahan tingkah laku kearah suatu tujuan tertentu (Morgan, 1986). Tingkat kehadiran dari dosen akan mendorong mahasiswa untuk hadir dalam kelas, dan hal ini sebagai motivasi, sehingga mereka dapat lebih berhasil dalam belajar.

Keberhasilan pendidikan merupakan keberhasilan nilai yang baik dengan tolak ukur tertentu. Sehingga sebagai suatu sistem pendidikan, masukan merupakan faktor yang dominan dalam menentukan arah proses pembelajaran untuk menghasilkan keluaran tertentu berdasarkan tujuan yang telah ditetapkan. Ukuran dari keberhasilan belajar mahasiswa menurut Zainul \& Nasution (1997) dapat dilihat dari dua hal (1) penggunaan angka dalam skala tertentu dan (2) menurut aturan atau formula tertentu. IPK merupakan Indikator keberhasilan belajar mahasiswa dalam skala angka relatif (1-4). Keberhasilan belajar baru dapat diukur jika sudah menggunakan informasi yang dilakukan melalui tes.

Agar sistem dapat berjalan memerlukan proses yang tepat dalam pembelajaran atau pendidikan. Secara makro sistem pendidikan agar dapat berjalan dengan baik merupakan integrasi dari 12 sub-sistem pendidikan. Antara dosen dengan mahasiswa merupakan sub-sistem tersendiri yang terjadi dalam suatu sistem pendidikan. Artinya bahwa sub-sistem merupakan 
bagian kecil (mikro) yang tidak dapat dipisahkan dari sistem pendidikan sehingga memerlukan strategi sendiri agar proses pembelajaran dapat menghasilkan keluaran yang sesuai dengan tujuan yang ditetapkan.

Secara mikro strategi dasar pembelajaran dalam sub-sistem ini (menurut Gagne dalam Suciati dan Irawan., Prasetya, 2001) yang dilakukan oleh Dosen (eksternal) untuk membantu proses belajar dalam diri mahasiswa (internal) terdiri dari sembilan strategi. (1) menimbulkan minat dan memusatkan perhatian mahasiswa salah satunya melalui kehadirannya dalam kelas. Dosen yang frekuensi kehadirannya tingga akan membuat segan mahasiswa untuk membolos. Selain itu kemampuan dan ketrampilan dalam upaya membangkitkan minat belajar mahasiswa ini merupakan bagian dari seni mengajar dosen dan memerlukan pemahaman tentang apa yang dapat menarik mahasiswa. (2) menyampaikan tujuan perkulihan. Hal ini dilakukan agar mahasiswa tidak menebak-nebak apa tujuan dirinya. Mereka perlu mengetahui unjuk kerja apa yang akan digunakan sebagai indikasi bahwa mereka sudah memahami suatu pengetahuan/ketrampilan sehingga tujuan mereka kuliah dan menjadi mahsiswa jelas. Cara ini sesuai dengan prinsip keterbukaan dan fairness. (3) mengingat kembali konsep/prinsip kuliah, sehingga apa yang telah mereka pelajari yang merupakan prasyarat untuk menempuh mata kuliah selanjutnya. Banyak pengetahuan baru yang merupakan kombinasi dari konsep-konsep atau informasi pengetahuan yang pernah dipelajari. Sehingga mahasiswa perlu mengingat kembali hal tersebut untuk dapat mempelajari teori baru dengan baik. (4) menyampaikan materi perkuliahan. Pada saat menyampaikan materi perkuliahan penekanan untuk menunjukan perbedaan atau bagian yang penting baik secara verbal maupun dengan menggunakan features tertentu (warna, meleingkari, menggarisbawahi dan sebagainya). Hal lainnya juga dapat menggunakan media pembelajaran yang inovatif. (5) memberikan Bimbingan Belajar melalui pertanyaan-pertanyaan yang membimbing proses/alur berpikir mahasiswa. Frekuensi bimbingan juga perlu ditingkatkan jika dirasakan kurang bagi mahasiswa, sehingga peran dosen dalam meluangkan waktu diluar kelas menjadi besar juga dimaksud untuk memberi jawaban kepada mahasiswa. Perlu juga menjadi perhatian bahwa bimbingan jangan dilakukan berlebihan,

Partisipasi Dosen Terhadap Hasil Belajar Mahasiswa Program Studi S-1 Pendidikan Teknik Sipil FT-UNJ (Nuriman Thoha, Dosen Jurusan Teknik Sipil FT-UNJ) 
sebab bagi mahasiswa yang cerdas hal ini dianggap meremehkan mereka sebaliknya akan tidak banyak membantu. (6) memperoleh unjuk kerja mahasiswa dengan menunjukan apa yang telah dipelajari, baik untuk menyakinkan dosen bahwa mahasiswa telah menguasahi materi, juga untuk meyakinkan mahasiswa sendiri. (7) memberikan umpan balik tentang kebenaran pelaksanaan tugas baik melalui diskusi diluar kelas maupun di dalam kelas. Hal ini untuk memberitahukan mahasiswa sejauh mana kebenaran atau unjuk kerja yang dihasilkan. (8) mengukur/mengevaluasi hasil belajar secara transparan dapat dilakukan melalui pemberian test atau tugas, (9) memperkuat retensi dan transfer belajar dapat ditingkatkan dengan mempelajari hal-hal yang dipelajari secara berulang menggunakan media/konteks yang berbeda. Hal lain juga melalui reviu atau pengulangan di saat-saat tertentu baik diluar kelas maupun di dalam kelas.

\section{Kerangka Berpikir dan Hipotesis}

Setiap individu mempunyai kemampuan belajar yang berlainan, sehingga hasilnya akan berbeda tergantung dari beberapa faktor salah satunya adalah Indikator partisipasi dosen dalam proses belajar. Partisipasi dosen ini diturunkan dari sembilan strategi pembelajaran yang selanjutnya dikembangkan sesuai dengan kebetuhan penelitian. Ukuran dari keberhasilan pada satu semester adalah Indek Prestasi Semester. Masa-masa awal atau pada tahun pertama dan kedua merupakan masa pembentukan, sehingga pada masa tahun ketiga diassumsikan mahasiswa sudah cukup mapan dalam belajar dan pada tahun keempat atau kelima (tahun akhir) sesuai dengan tujuan yang telah ditetapkan dalam visi dan misi program studi.

Sehubungan dengan hal diatas, dapat dikatakan bahwa jika partisipasi dosen tinggi maka dapat diduga bahwa materi yang diterima mahasiswa sesuai dengan rencana studi (kontrak kuliah) atau tujuan yang telah ditetapkan sehingga pengetahuan \& ketrampilan mahasiswa juga akan meningkat hal ini diduga akan mempengaruhi keberhasilan belajar mahasiswa.

Berdasarkan kerangka berpikir hipotesisnya adalah terdapat hubungan positif antara partisipasi dosen dengan hasil belajar mahasiswa yang ditunjukan dengan indeks prestasi kumulatif.

$$
H_{0}: r_{x, y}=0
$$




$$
\mathrm{H}_{1}: \mathrm{r}_{\mathrm{x}, \mathrm{y}}>0
$$

$r_{x, y}>0 \quad K o e f i s i e n$ korelasi antara partisipasi dosen atas hasil belajar mahasiswa.

\section{METODOLOGI PENELITIAN}

Penelitian ini berlokasi di Jurusan Teknik Sipil Fakultas Teknik Universitas Negeri Jakarta dari periode Agustus - Oktober 2004. Pelaksanaannya mengikuti tahapan; (1) Penelusuran referensi/kajian pustaka (2) Penjaringan Data melalui instrument pertanyaan dalam Tabel 1 dengan Jumlah sampel sebanyak 35 untuk yang telah menempuh minimal 4 semester atau lebih dari 40 SKS dan di ambil secara acak dari 199 mahasiswa. (3) Validasi data (4) Skoring data (5) Regresi dan (6) Pengujian hipotesis.

Tabel 1. Matrik Instrumen

\begin{tabular}{|c|c|c|}
\hline Variabel & Indikator & $\begin{array}{l}\text { No. Butir } \\
\text { Intrumen }\end{array}$ \\
\hline Kehadiran Dosen & $\begin{array}{l}\text { Menimbulkan minat dan memusatkan } \\
\text { perhatian mahasiswa }\end{array}$ & 1 \\
\hline Tujuan Kuliah & Menyampaikan Tujuan Perkulihan & 2 \\
\hline Konsep/Prinsip Kuliah & $\begin{array}{l}\text { Mengingat konsep yang sudah dipelajari } \\
\text { yang merupakan prasyarat }\end{array}$ & ri 3 \\
\hline $\begin{array}{ll}\text { Media } & \text { Pembelajaran } \\
\text { Inovatif } & \end{array}$ & Menyampaikan materi perkuliahan & 4 \\
\hline Frekuensi Bimbingan & Memberikan bimbingan belajar & 5 \\
\hline Unjuk Kerja Mahasiswa & Memperoleh unjuk kerja mahasiswa & 6 \\
\hline Diskusi/Umpan Balik & $\begin{array}{l}\text { Memberikan umpan balik tentang kebenaran } \\
\text { tugas }\end{array}$ & 7 \\
\hline $\begin{array}{l}\text { Transparansi } \\
\text { Evaluasi/Hasil Test }\end{array}$ & Mengukur/mengevaluasi hasil belajar & 8 \\
\hline Perkuatan Retensi & Memperkuat retensi dan transfer belajar & 9 \\
\hline
\end{tabular}

\section{HASIL DAN PEMBAHASAN}

\section{Deskripsi Data}

Distribusi responden berdasarkan jenis kelamin dari 35 data yang terjaring adalah laki-laki $45,7 \%$ dan perempuan 54,3\%. Komposisi responden 
berdasarkan SKS yang diambil adalah $40 \%$ responden telah mengambil $41-60$ SKS, masing-masing 14,3\% telah mengambil 61 - 80 SKS dan 81 - 100 SKS dan yang telah mengambil lebih dari 100 SKS sebesar 31,4\%. Berdasarkan data indek prestasi mahasiswa menunjukan bahwa 48,57\% responden dengan IPK 2,51 - 3,00, 34,29\% dengan IPK 2,0 - 2,5 dan IPK > 3,00 sebesar $14,29 \%$ serta kurang dari 2 sebesar 2,86\%. Deskripsi hasil penilaian responden terhadap partisipasi dosen disajikan di Tabel 2.

Tabel 2. Deskripsi Variabel Bebas

\begin{tabular}{l|l|l|l}
\hline Kode & Variabel & Mean & Std. Deviation \\
\hline X1 & Kehadiran Dosen & 3.09 & .61 \\
X2 & Tujuan Kuliah & 3.71 & .52 \\
X3 & Konsep/Prinsip Kuliah & 1.80 & .47 \\
X4 & Media Pembelajaran Inovatif & 2.09 & .51 \\
X5 & Frekuensi Bimbingan & 2.66 & .64 \\
X6 & Unjuk Kerja Mahasiswa & 2.11 & .76 \\
X7 & Diskusi/Umpan Balik & 2.09 & .45 \\
X8 & Transparansi Evaluasi/Hasil Test & 2.00 & .54 \\
X9 & Perkuatan Retensi & 3.00 & .59 \\
\hline
\end{tabular}

\section{Pengujian Persyaratan Analisis}

Pengujian keacakan telah dipenuhi dengan pengambilan sample secara acak dari sejumlah populasi mahasiswa. Pengujian normalitas dengan menggunakan uji Kolmogorov-Smirnov. Data indek prestasi kumulatif (IPK) mahasiswa dari hasil tes Kolmogorov-Smirnov memberikan harga 0,134 yang lebih kecil dari harga kritis $\left(D_{\text {tabel }}\right)$ 0.21. Hal ini menunjukan bahwa data responden berasal dari populasi yang terdistribusi normal. Selanjutnya dari hasil analisis data $X_{1}$ sampai $X_{9}$ merupakan data yang memenuhi unsur normalitas.

\section{Pengujian Hipotesis}

Hasil yang diperoleh untuk produk momen disajikan dalam matrik koefisien korelasi antar Variabel dalam Tabel 3. Variabel $X_{4}, X_{6}$ dan $X_{9}$ terhadap peningkatan IPK tidak berpengaruh banyak. Upaya penggunaan media $\left(\mathrm{X}_{4}\right)$ 
dapat disimpulkan bahwa teknologi (media inovatif) hanya sebagai alat bantu dan sangat tergantung dari dosennya sendiri. Begitu juga terhadap unjuk kerja mahasiswa $\left(X_{6}\right)$ yang ingin dibangkitkan oleh dosen dan upaya penguatan retensi $\left(X_{9}\right)$ melalui pengulangan materi tidak banyak membantu dalam peningkatan IPK mahasiswa. Dari koefisien korelasi tersebut berturut-turut akan dibahas mengenai pengujian hipotesi dari semua variabel yang mempunyai koefisien korelasi lebih besar dari 0,5 (hubungan yang kuat).

Tabel 3. Matrik Koefisien Korelasi Antar Variabel

\begin{tabular}{|c|c|c|c|c|c|c|c|c|c|c|}
\hline & $Y$ & $\mathrm{X} 1$ & $x 2$ & X3 & $X 4$ & $\times 5$ & X6 & $\times 7$ & X8 & X9 \\
\hline$Y$ & 1.000 & & & & & & & & & \\
\hline $\mathrm{X} 1$ & .629 & 1.000 & & & & & & & & \\
\hline$x 2$ & .881 & .450 & 1.000 & & & & & & & \\
\hline X3 & .769 & .467 & .840 & 1.000 & & & & & & \\
\hline$\times 4$ & -.046 & .165 & .096 & .074 & 1.000 & & & & & \\
\hline$\times 5$ & .833 & .378 & .938 & .837 & .003 & 1.000 & & & & \\
\hline X6 & -.264 & -.148 & -.139 & -.098 & .050 & -.160 & 1.000 & & & \\
\hline$X 7$ & .716 & .727 & .491 & .363 & -.033 & .416 & -.291 & 1.000 & & \\
\hline X8 & .606 & .709 & .523 & .344 & .107 & .424 & -.215 & .731 & 1.000 & \\
\hline X9 & .173 & .000 & .095 & .105 & -.293 & .155 & -.131 & .000 & .000 & 1.000 \\
\hline
\end{tabular}

\section{a. Hubungan antara Variabel bebas $\left(\mathrm{X}_{\mathrm{i}}\right)$ dengan Variabel Terikat $(\mathrm{Y})$}

Pada taraf signifikasi 0,05 hasil analisis regresi antara Variabel bebas $\left(X_{i}\right)$ dengan Variabel terikat $(\mathrm{Y})$ adalah sebagai berikut;

Hubungan antara Kehadiran dosen sebagai upaya membangkitkan minat dan perhatian mahasiswa oleh Dosen $\left(\mathrm{X}_{1}\right)$ dengan Indek Prestasi Kumulatif $(\mathrm{Y})$ ditunjukan dengan $Y=1,501+0,361 X_{1}$. Kekuatan hubungan 0,629 dan oefisien determinasi yang didapatkan sebesar 0,377 menunjukan bahwa variasi IPK hanya ditentukan atas 37,7\% kehadiran dosen. Hubungan Tujuan Kuliah yang disampaikan Dosen $\left(X_{2}\right)$ dengan $Y=1,395+0,598 X_{2}$, mempunyai kekuatan hubungan 0,881 dan koefisien determinasi 0,77 menunjukan bahwa variasi IPK hanya ditentukan atas $77 \%$ faktor mahasiswa. Hubungan antara menerangkan Konsep/Prinsip Kuliah $\left(X_{3}\right)$ atas $(Y)$ mempunyai persamaaan $Y=1,585+0,572$

Partisipasi Dosen Terhadap Hasil Belajar Mahasiswa Program Studi S-1 Pendidikan Teknik Sipil FT-UNJ (Nuriman Thoha, Dosen Jurusan Teknik Sipil FT-UNJ) 
$X_{3}$, kekuatan hubungan 0,769 dan koefisien determinasi yang didapatkan sebesar 0,579. Hubungan antara Frekuensi Bimbingan $\left(X_{5}\right)$ dengan $(Y)$ ditunjukan dengan $Y=1,397+0,459 X_{5}$. Kekuatan hubungan 0,833 dan koefisien determinasi yang didapatkan sebesar 0,685 menunjukan bahwa variasi IPK hanya ditentukan atas $68,5 \%$ banyaknya bimbingan kepada mahasiswa. Hubungan antara Diskusi/Umpan Balik $\left(X_{7}\right)$ dengan variabel $Y$ ditunjukan dengan $Y=1,436+0,565 X_{7}$, kekuatan hubungan 0,716 dan koefisien determinasi yang didapatkan sebesar 0,498 menunjukan bahwa variasi IPK hanya ditentukan atas 49,8\% upaya menumbuhkan budaya diskusi dikalangan mahasiswa. Hubungan antara malakukan transparansi dalam setiap Hasil Evaluasi $\left(X_{8}\right)$ dengan $Y=$ $1,830+0,393 X_{8}$, mempunyai kekuatan hubungan 0,606 dan koefisien determinasi yang didapatkan sebesar 0,348 menunjukan bahwa variasi IPK hanya ditentukan atas $34,8 \%$ upaya melakukan transparasi evaluasi hasil tes. Selanjutnya hasil analisis of varian memberikan nilai $F$ yang didapatkan lebih besar dari $F_{\text {tabel }}$ artinya bahwa model regresi di atas berarti dan garis persamaan yang didapat tidak berbentuk linier.

\section{b. Hubungan antara Variabel bebas (X) secara bersama-sama dengan Variabel Terikat (Y)}

Secara bersama-sama hubungan antara Variabel bebas $(\mathrm{X})$ dengan Variabel terikat $(Y)$ dinyatakan dengan $Y=0,363+0,063 X_{1}+0,336 X_{2}+0,0543$ $X_{3}+0,08247 X_{5}+0,291 X_{7}-0,0579 X_{8}$.

Tabel 4. ANOVA untuk Regresi Ganda

\begin{tabular}{l|l|l|l|l|l}
\hline $\begin{array}{l}\text { Sumber } \\
\text { Variasi }\end{array}$ & Jumlah Kuadrat & $\begin{array}{l}\text { Derajat } \\
\text { Kebebasan }\end{array}$ & $\begin{array}{l}\text { Kuadrat } \\
\text { Tengah }\end{array}$ & F & Sig. \\
\hline $\begin{array}{l}\text { Regression } \\
\text { Residual }\end{array}$ & 3.774 & 6 & .629 & 40.513 & .000 \\
\hline Total & 4.208 & 28 & $1.552 \mathrm{E}-02$ & & \\
\hline
\end{tabular}

Dari tabel 4 menunjukan bahwa signifikan dalam taraf nyata kurang dari 0,05 . Koefisein korelasi yang didapatkan sebesar 0,947 dapat dikatakan bahwa partisipasi dosen yang ditunjukan dengan kehadiran dosen (X1), menerangkan tujuan kuliah (X2), menerangkan konsep/prinsip dalam kuliah (X3), memberikan bimbingan (X5), melakukan diskusi atau memberikan umpan balik (X7) serta melakukan secara transparansi evaluasi hasil test (X8) mempunyai kekuatan 
hubungan sangat baik. Sehingga dapat diinterprestasikan bahwa semakin tinggi partisipasi dosen maka semakin baik pula kemungkinan hasil belajar mahasiswa yang ditunjukan melalui hasil indek prestasi kumulatif. Dari persamaan yang didapatkan Variabel X8 menunjukan pergerakan kearah negatif artinya bahwa semakin banyak dosen membahas hasil evaluasi test dan melakukannya secara terus menerus maka mahasiswa memandang akan berpengaruh negatif terhadap hasil IPK mereka. Hal ini logis, untuk sebagian mahasiswa yang introvert, membahas hasil evaluasi secara periodik akan membawa dampak negatif, sehingga perlu adanya strategi yang tepat. Koefisien determiniasi yang didapatkan sebesar 0,875 menunjukan bahwa 87,5\% variasi indek prestasi kumulatif mahasiswa ditentukan oleh adanya kontribusi partisipasi dosen, semakin tinggi maka akan semakin tinggi pula hasilnya.

\section{E. KESIMPULAN DAN SARAN}

Beberapa kesimpulan dapat diambil sebagai berikut: (1) Perbandingan responden berdasarkan jenis kelamin cukup mewakili antara laki-laki $(45,7 \%)$ dan perempuan (54,3\%). Berdasarkan jumlah sks yang sudah diambil responden prosentase terbesar berada pada rentang antara 41 - 60 SKS ini merupakan mahasiswa yang masih sangat membutuhkan partisipasi dosen dalam meningkatkan hasil belajarnya. IPK responden terbesar berada antara 2,51 3,00 yaitu sebesar $48,57 \%$. (2) Penilaian responden terhadap partisipasi dosen yang meliputi kehadiran dosen, tujuan kuliah dan perkuatan retensi dirasakan cukup oleh responden. Penilaian responden terhadap konsep/prinsip kuliah, penggunan media inovatif, frekuensi bimbingan, unjuk kerja mahasiswa, diskusi/umpan balik, transparansi evaluasi/hasil tes dirasakan masih kurang. (3) Hasil pengujian normalitas dan homogenitas dengan uji Kolmogorov-Smirnov pada taraf nyata 0,05 untuk semua variabel memenuhi unsur normalitas dan homogenitas. (4) Hubungan antara variabel terikat $(Y)$ dengan sembilan variabel bebas $(X)$ yang mempunyai angka korelasi lebih dari 0,5 atau hubungan yang kuat hanya menghasilkan lima variabel yaitu; kehadiran dosen $\left(X_{1}\right)$ dengan persamaan regresi $Y=1,501+0,361 X_{1}$, Tujuan kuliah $\left(X_{2}\right)$ mempunyai hubungan regresi $Y=1,395+0,598 X_{2}$, Konsep/Prinsip Kuliah $\left(X_{3}\right)$ persamaannya adalah $Y=1,585+0,572 X_{3}$, Frekuensi Bimbingan $\left(X_{5}\right)$

Partisipasi Dosen Terhadap Hasil Belajar Mahasiswa Program Studi S-1 Pendidikan Teknik Sipil FT-UNJ (Nuriman Thoha, Dosen Jurusan Teknik Sipil FT-UNJ) 
memberikan hubungan $Y=1,397+0,459 X_{5}$, Diskusi/umpan Balik $\left(X_{7}\right)$ dengan $Y$ $=1,436+0,565 X_{7}$, dan transparansi Evaluasi/hasil tes $\left(X_{8}\right)$ memberikan persamaan regresi $Y=1,830+0,393 X_{8}$. (5) Analisis varian untuk model regresi sederhana yang didapat memberikan bahwa model persamaan berarti. (6) Hubungan antara variabel bebas $(X)$ secara bersama-sama dengan variabel terikat $(Y)$ dalam regresi ganda pada taraf signifikasi 0,05 dengan kekuatan hubungan 0,947 menghasilkan persamaan; $Y=0,363+0,063 \mathbf{X}_{\mathbf{1}}+\mathbf{0 , 3 3 6} \mathbf{X}_{\mathbf{2}}+$ $0,0543 X_{3}+0,08247 X_{5}+0,291 X_{7}-0,0579 X_{8}$. Koefisien determinasi yang didapatkan sebesar 0,875 menunjukan bahwa 87,5\% variasi indek prestasi kumulatif mahasiswa ditentukan oleh adanya kontribusi partisipasi dosen, semakin tinggi maka akan semakin tinggi pula hasilnya.

Dari kesimpulan di atas dapat ditarik beberapa saran untuk kepentingan dalam upaya meningkatkan kinerja jurusan melalui partisipasi dosen dalam meningkatkan keberhasilan belajar mahasiswa adalah: (1), perlu ditingkatkan lagi kehadiran dosen dalam upaya membangkitakan minat belajar mahasiswa sehingga dapat tercipta iklim akademik yang lebih kondusif. (2) perlu ditingkatkan lagi tujuan kuliah mahasiswa sehingga kesadaran akan tujuan dan prinsip yang sebenarnya dalam kuliah dapat lebih baik bukan hanya sebagai pencarian gelar akan tetapi lebih kearah professional skill. Upaya ini dapat melalui bimbingan yang lebih itensif. (3) diskusi dan selalu memberikan umpan balik serta transparansi evaluasi atau hasil tes dengan selalu mengembalikan hasil-hasil tes sebagai upaya lain dari partisipasi dosen diharapkan dapat ditingkatkan sehingga keberhasilan belajar mahasiswa dapat lebih baik. (4) upaya meningkatkan partisipasi dosen saat ini dalam rangka meningkatkan keberhasilan belajar mahasiswa dil ingkungan Jurusan Teknik Sipil - Fakultas Teknik - Universitas Negeri Jakarta lebih banyak merupakan dorongan moral dosen sendiri. Upaya ini dapat lebih baik jika dibuat sebuah aturan mengenai reward (penghargaan) dan punishment (sanksi) sehingga tuntutan dan kewajiban sebagai dosen dapat seimbang.

\section{DAFTAR PUSTAKA}

Armer, Michael and Youtz, Robert, Formal Education and Individual Modernity in An African Society, American Journal Sociology, Vol.76, pp.27-69. 
Irawan, P, Suciati, dan Wardani, I.G.A.K, Teori Belajar, Motivasi, dan Ketrampilan Mengajar, Cetakan Ke-6, Jakarta: PAU-PPAI Universitas Terbuka, 1997

Soekamto, Toeti,. Teori Belajar, Cetakan Ke-enam, Jakarta: PAU-PPAI, Universitas Terbuka, 1997.

Zainul, Asnawi., dan Nasoetion, Noehl, Penilaian Hasil Belajar, Cetakan Keenam, Jakarta: PAU-PPAI, Universitas Terbuka, 1997.

Pannen., Paulina, Pendidikan Sebagai Sistem, Pusat Antar Universitas untuk Peningkatan dan Pengembangan Aktivitas Instruksional DirJend Pendidikan Tinggi Depdiknas, 2001.

Suciati dan Irawan., Prasetya, Teori Belajar dan Motivasi, Pusat Antar Universitas untuk Peningkatan dan Pengembangan Aktivitas Instruksional DirJend Pendidikan Tinggi Depdiknas, 2001. 